College of William \& Mary Law School William \& Mary Law School Scholarship Repository

\title{
Asking the Right Questions: How the Courts Honored the Separation of Powers by Reconsidering Miranda
}

Neal Devins

William \& Mary Law School, nedevi@wm.edu

\section{Repository Citation}

Devins, Neal, "Asking the Right Questions: How the Courts Honored the Separation of Powers by Reconsidering Miranda" (2000).

Faculty Publications. 362.

https://scholarship.law.wm.edu/facpubs/362

Copyright c 2000 by the authors. This article is brought to you by the William \& Mary Law School Scholarship Repository. 


\title{
POINT / COUNTERPOINT
}

\author{
ASKING THE RIGHT QUESTIONS: HOW THE COURTS \\ HONORED THE SEPARATION OF POWERS BY \\ RECONSIDERING MIRANDA
}

\author{
NEAL DEVINS ${ }^{\dagger}$ \\ INTRODUCTION
}

By putting an end to a thirty-five year campaign to nullify Miranda v. Arizona, did the federal judiciary engage in inappropriate judicial activism or appropriate judicial restraint?

At first blush, the answer to this question seems simple, namely: the Miranda override litigation is an obvious, blatant example of judicial overreaching. In deciding whether Congress could statutorily nullify Miranda, the Fourth Circuit Court of Appeals and the Supreme Court both reached out to decide an issue that simply was not a part of the case. Neither party to the case, Dickerson v. United States, ${ }^{2}$ called attention to a 1968 statute $^{3}$ providing that police need not issue Miranda warnings. ${ }^{4}$ Instead, both sides agreed that Miranda was the appropriate benchmark in weighing the admissibility of a confession. ${ }^{5}$ Consequently, by first looking to the 1968 statute, not Miranda, to sort

† Goodrich Professor of Law and Lecturer in Government, College of William and Mary. Special thanks are owed to James Beers for exceptional research assistance as well as Tammy Meyer and Char Riec for their research help. For generous comments, I thank Susan Bandes, Mike Dorf, Scott Idleman, Neal Katyal, John McGinnis, Mike Paulsen, Sai Prakash, Bob Pushaw, and Connie Taylor. Thanks also to numerous William and Mary colleagues who read and commented on a draft of this paper at a worksin-progress colloquium; in particular, John Duffy played an instrumental role in the crafting of this essay. I also benefited from comments at faculty workshops at Washington \& Lee and Boston College law schools. Finally, I want to thank Erwin Chemerinsky both for serving as such a wonderful foil in this point/counterpoint and for being such a good friend.

' 384 U.S. 436 (1966).

120 S. Ct. 2326 (2000).

${ }^{3}$ Omnibus Crime Control and Safe Streets Act of 1968,18 U.S.C. $\$ 3501$ (1994)

(held unconstitutional by Dickerson v. United States, 120 S. Ct. 2326 (2000)).

166 F.3d 667 (4th Cir. 1999), rev'd, 120 S. Ct. 2326 (2000).

s. Id. 
out the admissibility of a confession, the Fourth Gircuit committed plain error. After all, a central tenet of our adversarial system is that (save for jurisdictional issues) the parties to a case-not the judges deciding the case-raise the legal arguments. ${ }^{6}$ For its part, the Supreme Court, by granting certiorari to decide the constitutionality of the 1968 statute, played fast and loose with the Constitution's "case or controversy" requirement. ${ }^{7}$ With neither party willing to defend the statute, ${ }^{8}$ the Justices - to preserve the semblance of an adversarial dispute-appointed counsel to argue the "government's side" of the case. $^{9}$

This characterization of Dickerson is widely shared. In particular, depicting the Fourth Circuit as "'an assistant teeing up issues for the Supreme Court and scouting new enemies to conquer" ${ }^{\prime 10}$ and "the flagship of the federal judiciary's increasingly aggressive conservative wing," academics and journalists alike have savaged the appellate court for sua sponte considering the 1968 statute. ${ }^{12}$ Complaining that

\footnotetext{
${ }^{6}$ At an early stage in the litigation, the Justice Department argued that the Dickerson confession was admissible under the 1968 statute. Pretrial Rehearing Brief for the United States at 2 n.1, United States v. Dickerson, 166 F.3d 667 (4th Cir. 1999) (No. $97-4750$ ) (copy on file with author). By the time Dickerson made its way to the appellate court, however, the government elected to limit its arguments to Miranda, not the 1968 statute. See Dickersom, 166 F.3d at 680-81 (noting the government did not brief the applicability of $\$ 3501$ on appeal).

${ }^{7}$ U.S. CONST. art III, \$ 2.

${ }^{8}$ Dickerson v, United States, 120 S. Ct. 578 (1999) (mem).

"Id. Technically, the Court appointed Paul Cassell "amicus curiae" to defend the constitutionality of the 1968 statute. Id. ("Paul G. Cassell, Esquire, of Salt Lake City, Utah, is invited to brief and argue this case, as amicus curiae, in support of the judgment below."). Cassell, a University of Utah law professor and Washington Legal Foundation lawyer, has dedicated himself to the undoing of Miranda through the writing of articles and the filing of briefs. See Terry Carter, The Man Who Would Undo Miranda, A.B.A. J., Mar. 2000, at 44 (profiling Cassell). Before the Fourth Circuit, moreover, Cassell sought and was granted permission to defend the statute through the filing of an amicus brief and the presentation of oral arguments. See Dickerson, 166 F.3d at 680-81 n.14 (explaining why it granted the Washington Legal Foundation's motion to participate in the Dickerson litigation).

${ }^{10}$ Brooke A. Masters, 4th Circuit Pushing to Right, WASH. POST, Dec. 19, 1999, at C-1 (quoting Akhil K. Amar, Yale University law professor).

${ }^{11}$ Garrett Epps, Playing Supreme Count with Privacy: 4th Circuit Went Too Far in Reno v. Condon, Legal Times, Nov. 8, 1999, at 58; see also Vivian Berger, Don't Mourn Miranda Yet, NAT'L. L.J., Sept. 20, 1999, at A-22 (noting the Fourth Circuit is "the court of appeals most viscerally hostile to defendants' rights"); Carrie Johnson, Testing the Limits: 4th Circuit's Conservative Push to High Court, LEGAL TIMES, Oct. 4, 1999, at 1; Brooke A. Masters, 4th Circuit Is Steering Hard to the Right, WASH. POST, July 5, 2000, at B-1 (stating that the Dickerson decision was the 4th Circuit's biggest loss of the Supreme Court's term).

${ }^{12}$ See, e.g., Stephen J. Schulfofer, 'Miranda' Now on the Endangered Species List, NAT'L
} 
the Fourth Circuit was animated by a desire to undo Miranda, critics deemed the decision "a heavy dose of conservative judicial activism" and "the most surprising and ill-considered instance of "judicial activism' in recent memory. ${ }^{\text {,1 }}$ In reversing the Fourth Circuit, the Supreme Court too has been criticized for using Dickerson as a vehicle to advance its ideological preferences. By declaring that Congress cannot overturn Court-created constitutional norms, ${ }^{15}$ the Court's reaffirmation of Miranda has been portrayed as part and parcel of a Rehnquist Court campaign to limit congressional power. For example, commenting that " $[t]$ here might well have been a period, sometime in the last three decades, when the Court would have overturned Miranda," The New York Times's Linda Greenhouse argues that "timing" explained the Court's decision: the fact that "the [C]ourt's interest in protecting its constitutional turf against congressional incursions was at a peak unmatched in recent years."

In the pages that follow, I will take issue with this prevailing wisdom. Pointing to the judiciary's Article III duty to decide cases according to the law, I will argue that the Fourth Circuit was correct in paying attention to Congress's mandate that the 1968 statute, not Miranda, set out the "law" governing the admissibility of confessions. ${ }^{17}$

L.J., Mar. 1, 1999, at A-22 (describing the Fourth Circuit's decision as "an extraordinary act of judicial buccaneering"); Stuart Taylor, Jr., Raising Miranda: Will the Supreme Court Remain Silent?, LEGAL TIMES, Oct. 25, 1999, at 67 (describing how the Fourth Circuit overruled Miranda even though the Department of Justice had not questioned its applicability).

Taylor, supra note 12 , at 67.

${ }^{14}$ Schulhofer, supra note 12, at A22.

${ }^{15}$ Dickerson, 120 S. Ct. at 2329.

tit Linda Greenhouse, A Turf Battle's Unlikely Victim, N.Y. TIMES, June 28, 2000, at A20; see also Tony Mauro, Split Branches: Little Deference to Congress as Court Curbs Federal Power, LEGAL TIES, May 22, 2000, at 1 (quoting a speech by Justice Scalia, suggesting that the Supreme Court should no longer presume acts of Congress to be constitutional because Congress takes the attitude that "it will do anything it can get away with and let the Supreme Court worry about the Constitution'"). For other news analyses calling attention to the ongoing battle between the Court and Congress, see Linda Greenhouse, Supreme Court: The Justices Decide Who's in Charge, N.Y. TIMES, June 27, 1999, at 4-1 (noting the Court's lack of deference to Congress's federal legislation views); Suzanna Sherry, Some Targets Were Larger than Others, WASH. POST, July 4, 1999, at B4 (indicating the Court's term was highlighted by invalidating federal legislation that violated state's rights). Ironically, had the Supreme Court ruled the other way in Dickerson, it-like the Fourth Circuit-would have been criticized for its opportunistic, ideological repudiation of Miranda.

17 This is not to say that the Fourth Circuit was correct in concluding that the 1968 statute was constitutional. My point is simply that, if constitutional, the 1968 statute trumped Miranda. See infra notes 59-65 and accompanying text (explaining that judicial powers are limited and that the courts must enforce applicable laws). 
Otherwise, litigants could effectively direct courts to decide cases according to their policy preferences, not the law. At the same time, the Clinton administration was not obligated to defend the constitutionality of the 1968 statute. The executive's Article II power to interpret the Constitution certainly extends to the Clinton Justice Department's decision to argue that the 1968 statute was unconstitutional but that Dickerson's confession was admissible under Miranda. Faced with a real dispute over the confession's admissibility but unable to direct the government to defend the 1968 statute, the Supreme Court was right in appointing counsel to defend the 1968 statute.

None of this is to say that ideology did not animate either the Fourth Gircuit or the Supreme Court. ${ }^{18}$ It is to say, however, that core separation of powers principles support the decisions both to consider the 1968 statute and to appoint outside counsel to defend the statute's constitutionality. In other words, while the line separating judicial activism from judicial restraint may be murky, the responsibility for each branch of government to independently interpret the law is clear.

\section{Preliminaries}

In our tripartite system of government, a system of checks and balances, each branch is empowered to independently interpret the Constitution and, in so doing, to serve as a bulwark against the aggrandizement of too much power in any other branch. Furthermore, each branch possesses core powers-powers that cannot be delegated to another branch. Consider the relationship of the judiciary to the executive. On the one hand, since the "judicial power of the United States" is vested in federal courts, ${ }^{19}$ Congress could not transfer this power to executive agencies. "That would be to sap the judicial power as it exists under the Federal Constitution, and to establish a government of a bureaucratic character alien to our system .... ${ }^{20}$ At the

${ }^{18}$ See supra notes 10-16 and accompanying text (calling attention to claims that both the Fourth Circuit and the Supreme Court were politically motivated); see also Erwin Chemerinsky, The Court Should Have Remained Silent: Why the Court Erred in Deciding United States v. Dickerson, 149 U. PA. L. REV. 287, 291 (suggesting that the Fourth Circuit was animated by ideology); infra note 102 (same). For a treatment of the role of ideology in judicial decisionmaking, see generally LEE EPSTEIN \& JACK KNIGHT, THE CHOICES JUSTICES MAKE (1998) (providing an overview of ideological decisionmaking).

${ }^{19}$ U.S. CONST. art III, § 1.

${ }^{20}$ Crowell v. Benson, 285 U.S. 22, 57 (1932). Since Crowell was decided, of course, administrative agencies have assumed more and more judicial functions. Nevertheless, their orders are subject to review by an Article III court. 
same time, the judiciary must respect the executive's power to enforce the law. For example, the executive possesses prosecutorial discretion: the power to launch prosecutions, introduce evidence, and the like. As such, it would be impermissible for a federal court to assume the role of prosecutor by, say, introducing into evidence a confession that the executive deemed inadmissible.

What then of the Dickerson litigation? Here, the executive introduced into evidence a confession that it deemed admissible under Miranda, the standard it employs in assessing confessions. ${ }^{21}$ And while the criminal defendant, Charles Dickerson, thought the confession should be suppressed, Dickerson agreed with the government that Miranda was the governing rule of law. ${ }^{22}$ By applying a different rule of law than the one subscribed to by both the government and Dickerson, the appeals court put its desire to "say what the law is" ahead of the executive's desire to define criminal prosecutions.

How can I say that this decision is grounded in the separation of powers, not a usurpation of prosecutorial discretion-a core executive power. ${ }^{23}$ More fundamentally, in the absence of a concrete dispute over the appropriate legal standard, how can I say that the separation of powers requires federal courts to sua sponte raise the 1968 statute?

Let me begin with a confession. When I began thinking about this project, my first impulse was to write a paper condemning conservatives for engaging in the same type of activism that conservatives have long accused liberal judges of, that is, reaching out to decide cases to make law, not resolve concrete adversarial disputes. Specifically, in campaigning against "judicial activism," Ronald Reagan and other conservatives bemoaned "a weakening of the court's resolve to

21 "On January 27, 1997, Charles T. Dickerson confessed to robbing a series of banks in Maryland and Virginia." United States v. Dickerson, 166 F.3d 667, 671 (4th Cir. 1999). According to the government, Dickerson was read (and waived) his Miranda rights. Id. at 675-76.

${ }^{21}$ According to Dickerson, the confession took place before the reading of his Miranda rights. Id. at 674-76. The United States District Court for the Eastern District of Virginia sided with Dickerson and, consequently, suppressed the confession. See United States v. Dickerson, 971 F. Supp. 1023, 1023-25 (E.D. Va. 1997) (upholding its previous decision to suppress certain evidence that was gathered in violation of Dickerson's constitutional rights), rev'd, 166 F.3d 667 (4th Cir. 1999), rev'd, 120 S. Ct. 2326 (2000).

23 In Dickersom, an amicus brief filed by former Attorney General Benjamin Civiletti argues that, by raising the 1968 law sua sponte, the Fourth Circuit undermined core executive powers. Brief of Benjamin R Civiletti, Amicus Curiae, Dickerson v. United States, $120 \mathrm{~S}$. Ct. 578 (1999) (No. 99-5525). For reasons detailed below, I think this position is incorrect. See infra notes 63-67 and accompanying text. 
abide by the case or controversy requirement."24 Indeed, Reagan's first Attorney General, William French Smith, "pledged on taking office... that cases should not be adjudicated where the party bringing the case had only a remote connection with the issues; where the underlying dispute was not 'ripe' ... and where the matter was properly resolved by the political branches, Congress or the executive." cordingly, for Smith and other conservatives, the separation of powers demands that courts should only review those issues that are truly in controversy and therefore represented by vigorous advocacy. ${ }^{26}$

On the surface, the Miranda override litigation appears to be precisely the type of case that Smith had in mind. With no adversarial dispute on the governing substantive legal rule, the question of whether prosecutors should utilize the 1968 statute seemed a political matter best resolved by Congress and the executive, not the courts. To determine whether Congress had overruled Miranda, a court (or so I thought) would have to eschew this "dispute resolution" model in favor of the so-called "public values" model of adjudication. ${ }^{27}$ Under the public values model, "the function of the judge ... is not to resolve disputes, but to give the proper meaning to our public values. ${ }^{28}$ Con-

\footnotetext{
${ }^{24}$ WILLIAM FRENCH SMITH, LAW AND JUSTICE IN THE REAGAN ADMINISTRATION 59 (1991).

${ }^{25}$ SMrTH, supra note 24 , at 60 . Under this view, when the basis for decision falls
} outside the framework of the litigants' arguments, "the adjudicative process has become a sham, for the parties' participation in the decision has lost all meaning." Lon L. Fuller, The Forms and Limits of Adjudication, 92 HARV. L. REV. 353, 388 (1978). Relatedly, "[a]n adversary presentation seems the only effective means for combating the natural human tendency to judge too swiftly in terms of the familiar that which is not yet fully known." $I d$. at 383 .

${ }^{26}$ For these conservatives, "the premise of our adversarial system" has always been that federal courts "do not sit as self-directed boards of legal inquiry and research, but essentially as arbiters of legal questions presented and argued by the parties before them." Lebron v. Nat'1 R.R. Passenger Corp., 513 U.S. 374, 408 (1995) (O'Connor, J., dissenting) (quotation marks omitted).

${ }^{27}$ See generally Evan Tsen Lee, Deconstitutionalizing Justiciability: The Example of Moolness, 105 HARV, L. REV, 603, 625-28 (1992) (presenting these two models of adjudication).

${ }^{23}$ Owen M. Fiss, The Supreme Court, 1978 Term: Foreword: The Forms of Justice, 93 HARV, L. REV. 1, 30 (1979). For proponents of this model, "the fundamental conception of litigation as a mechanism for private dispute settlement is no longer viable. The argument is about whether or how a government policy or program shall be carried out." Abram Chayes, The Role of the Judge in Public Law Litigation, 89 HARV. L. REV. $1281,1294-95$ (1976). Correspondingly, "justice comes not from individual participation, but from the process of giving meaning to constitutional values." Susan Bandes, The Idea of a Case, 42 STAN. L. REv. 227, 287 (1990); see also Neal Kumar Katyal, Judges as Advicegivers, 50 STAN. L. REV. 1709, 1822 (1998) (defending judicial advicegiving as a way to "aid our governments in the task of serving their master-the American peo- 
sequently, concrete adverseness, while perhaps necessary to commence litigation, "becomes unimportant, whatever the stage of litigation, since the primary goal is to resolve the issue, not to settle a dispute between parties. ${ }^{29}$ In Dickerson, the fact that the government and Dickerson disagreed over the admissibility of the confession was more than sufficient adversiveness to support judicial resolution of any and all related questions.

At first blush, the Dickerson litigation seemed like a textbook example of the profound difference between the "public values" and "dispute resolution" models. For this very reason, a project calling attention to the willingness of conservatives, both judges and interest groups like the Washington Legal Foundation, to compromise their views on the judicial role in order to advance their policy preferences seemed worth doing. It would highlight the difficulty of placing something as abstract as a vision of the separation of powers ahead of something as concrete as desired policy outcomes. ${ }^{30}$

The longer I researched and thought about this issue, however, the more I came to doubt my original impulse. More to the point, as I will now argue, the sua sponte raising of the 1968 statute and the appointment of amicus curiae to defend the statute's constitutionality is consistent with the "dispute resolution" model of litigation. At its core, the "dispute resolution" model calls upon courts to see Article III as a limited grant of jurisdictional authority. ${ }^{31}$ Consequently, in order to respect the primacy of elected government decisionmaking, federal courts must vigilantly police the boundaries of their Article III powers. Accordingly, starting with Marbury $v$. Madison, the federal

ple").

${ }^{23}$ Bandes, supra note 28, at 290. For an argument that the Framers understood the main purpose of the judiciary in Article III "cases" to be the expounding of federal law, see Robert J. Pushaw Jr., Article III's Case/Controversy Distinttion and the Dual Functions of Federal Courts, 69 NOTRE DAME L. REV. 447 (1994). For a sampling of articles highlighting the Supreme Court's sometimes-willingness to embrace the public values model, see Bandes, supra note 28, at 283 n.386; Gene R. Nichol, Jr., Rethinking Standing. 72 CAL. L. REV. 68 (1984); Girardeau A. Spann, Proposition 209, 47 DUKE L.J. 187 (1997).

Nelson Lund made a similar point in Lawyers and the Defense of the Presidency, 1995 B.Y.U. L. REV. 17, an article which showcased the willingness of the Bush administration to sacrifice its conception of Article II power in order to advance short-term policy priorities. See also John O. McGinnis, Impeachable Defenses, 95 POL'Y REV, 27 (1999) (calling attention to the willingness of left-leaning academics to embrace originalisman interpretive theory they disavow in their writings-in arguing that President Clinton should not be impeached).

${ }^{31}$ Questions of jurisdiction "should be given priority-since if there is no jurisdiction there is no authority to sit in judgment of anything else." Vt. Agency of Natural Res. v. United States ex rel. Stevens, 120 S. Ct. 1858, 1865 (2000). 
courts have sua sponte raised jurisdictional issues, ${ }^{32}$ For example, if a litigant lacks standing to sue, it is the judiciary's responsibility to dismiss the case - that opposing counsel may not have called attention to the standing issue is irrelevant.

In the typical case, the "dispute resolution" model would see the absence of adversariness as proof positive that the court is without jurisdiction. Dickerson, however, is far from typical. The Department of Justice and the criminal defendant disagreed about whether there was proof to support a criminal conviction. Far more significant (for my purposes), the two sides disagreed over the admissibility of Dickerson's confession. ${ }^{33}$ In short, it is clear that the courts had jurisdiction over Dickerson, including jurisdiction over the admissibility of the confession. The question then becomes whether, in resolving this dispute, the court's power necessarily includes the power to take into account the 1968 statute. In part, this is a question of jurisdiction, namely: before determining whether Dickerson's confession is admissible under Miranda, is the question of the 1968 statute's applicability a jurisdictional prerequisite? ${ }^{34}$ Alternatively, in exercising its Article III power to decide the confession's admissibility, may a federal court consider legal arguments that it deems relevant but are not raised by either party?

\section{ARTICLE III AND THE DUTY TO "SAY WHAT THE LAW IS"}

The very idea of an independent judiciary is grounded in the belief that it is for the courts to "say what the law is." During the $1780 \mathrm{~s}$, the founders thought it "necessary to guarantee the judges' independence and integrity" in response to a growing mistrust of elected

\footnotetext{
${ }^{32}$ In the Marbury litigation, the litigants did not question the jurisdictional authority of the Supreme Court. Madison did not appear before the Court, choosing instead to ignore the lawsuit. Marbury's counsel, Charles Lee, not surprisingly did not call into question the Supreme Court's power to issue a writ of mandamus. See Marbury v. Madison, 5 U.S. (1 Cranch) 137, 146-53 (1803) (suggesting the parties failed to raise jurisdictional issues the Court raised on its own).

${ }^{33}$ See supra notes 21-22 and accompanying text (noting the parties' disagreement over whether Dickerson confessed before he was read his Miranda rights).

${ }^{34} \mathrm{See}$ infra notes 72-78 and accompanying text (discussing the tension between $\$ 3501$ and Miranda).

${ }^{35}$ Sometimes, of course, it is for the political branches to say what the law is. On political questions, like impeachment, the power to "say what the law is" resides in the political branches. Furthermore (and far more significantly), the political branches regularly interpret the Constitution. See infra notes 83-87 and accompanying text (discussing the power of presidential review).
} 
government, especially the legislatures. ${ }^{36}$ In The Federalist No. 78, Hamilton likewise spoke of the need for the judiciary to remain "truly distinct from both the legislative and the executive" and, in so doing, for the courts to keep elected officials "within the limits assigned to their authority. ${ }^{37}$ Accordingly, the "interpretation of the laws is the proper and peculiar province of the courts., ${ }^{38}$

This belief in an independent judiciary is very much tied to the notion that the "rule of law" should triumph over the "rule of men." By insisting that the political branches "act through general, public rules," the founders embraced "a higher or constitutional law that governs ordinary lawmaking, as well as politically independent courts of law to enforce this higher law against public officials." the founders saw independent courts testing the legality of government decisionmaking as the best hope of maintaining the rule of law and, with it, protecting citizens against tyranny.

Consider, for example, the Supreme Court's 1995 decision in Plaut $v$. Spendthrift Farm Inc. ${ }^{41}$ Concluding that Congress cannot require federal courts to reopen final judgments, the Court invalidated amendments to the Securities and Exchange Act of 1934 allowing for the reopening of lawsuits that had been dismissed on technical grounds, namely, the failure to file within the (then pertinent) statutory timelines. ${ }^{42}$ Pointing to the Framers' "sense of a sharp necessity to separate the legislative from the judicial power, ${ }^{43}$ the Court approvingly cited language from The Federalist No. 81 that "[a] legislature without exceeding its province cannot reverse a determination once made, in a particular case; though it may prescribe a new rule for fu-

5. GORDON S. WOOD, THE CREATION OF THE AMERICAN REPUBLIC: $1776-1787$, at 456 (1969).

${ }^{37}$ THE FEDERALIST No. 78, at 523-25 (Alexander Hamilton) (Jacob E. Cooke ed., 1961).

Id. at 525 .

"See Emest Weinrib, The Intelligibility of the Rule of Law, in THE RULE OF LAw: IDEAL OR IDEOLOGY 59, 62-63 (Alan C. Hutchinson \& Patrick Monahan eds., 1987) (distinguishing Plato's belief in the "rule of men" from Aristotle's belief in the "rule of law").

Stephen Macedo, The Rule of Law, Justice, and the Politics of Moderation, in THE RULE OF LAW 148, 149 (Ian Shapiro ed., 1994). This is not to say, however, that courts ought to issue advisory opinions, comment on nongermane legal issues through dicta, and the like. It is to say, instead, that-when courts have jurisdiction to decide-the law, not the arguments of litigants, should control.

${ }^{41} 514$ U.S. 211 (1995).

12 See id. at 240 (holding the amendment unconstitutional "to the extent that it requires federal courts to reopen final judgments entered before its enactment").

${ }^{43}$ Id. at 221. 
ture cases." ${ }^{\text {44 }}$ By separating the judicial power "not merely to rule on cases, but to decide them" from the legislative power to prescribe rules, Plaut makes clear that popular government cannot interfere with the court's power to interpret the laws. ${ }^{45}$

Plaut, of course, is little more than a modern day application of Marbury v. Madison. ${ }^{46}$ Marbury, by declaring that "[i]t is emphatically the province and duty of the judicial department to [s] ay what the law is," speaks to the Court's power and obligation to decide cases in accordance with the governing law. ${ }^{47}$ And while Marbury is especially concerned with the constitutionality of elected government decisionmaking, the question of whether or not government conforms to its legal obligations is certainly at the heart of the decision. ${ }^{48}$ Correspondingly, in holding that courts can order government officials to comply with the law, ${ }^{49}$ Marbury makes clear that no one is above the law and, accordingly, that courts will not facilitate disobedience to the law. ${ }^{50}$

Like The Federalist No. 78, Marbury equates judicial independence with the power to "say what the law is." As such, it is well established that parties to a dispute cannot agree to bind the court on stipulated questions of law. Otherwise, the rule of men would triumph over the rule of law. For this reason, "[w] hen an issue or claim is properly before the court, the court is not limited to the particular legal theories advanced by the parties, but rather retains the independent power to

41 Id. at 222 (quoting THE FEDERALIST NO. 81, at 545 (Alexander Hamilton) (Jacob E. Cooke ed., 1961)).

45. Id. at 218-19.

${ }^{46} 5$ U.S. (1 Cranch) 137 (1803).

${ }^{17}$ Id, at 177; see also James S. Liebman \& William F. Ryan, "Some Effectual Power"; The Quantily and Quality of Decisionmaking Required of Article III Courts, 98 COLUM. L. REv. 696, 711-15 (1998) (discussing the development of the federal courts at the Constitutional Convention).

${ }^{43}$ See DAVID P. CURrie, Federal JuRisdiction in A NUTShell 5 (3d ed. 1990) (discussing two theories of judicial review in Marbury); Henry P. Monaghan, Constitutional Adjudication: The Who and When, 82 YALE L.J. 1363, 1370-71 (1973) (discussing the role of the courts in a system of limited government); Henry P. Monaghan, Marbury and the Administrative State, 83 COLUM. L. REV. 1, 11 (1983) (arguing that "an article III court cannot be 'jurisdictionally' shut off from full consideration of the substantive constitutional issues").

${ }^{49}$ See Marbury, 5 U.S. (1 Cranch) at 180 (concluding that courts are bound by the Constitution).

so See Dean Alfange, Jr., Marbury v, Madison and Original Understandings of Judicial Review: In Defense of Traditional Wisdom, 1993 SuP. CT. REV. 329, 378-79 (discussing why Marbury stood for the concept that no person is above the law). 
identify and apply the proper construction of governing law." ${ }^{51}$ Furthermore, since " $[t]$ he public interest that a result be reached which promotes a well-ordered society is foremost in every criminal proceeding .... the proper administration of the criminal law cannot be left merely to the stipulation of parties. ${ }^{\text {n52 }}$

The duty of courts to look to the law, not just the arguments of litigants, implies that courts can, among other things, undertake independent research to sort out the relevant law, consider the arguments of amici, and address issues necessary to the resolution of the case that neither party raises in briefs or oral arguments. ${ }^{53}$ For example, in Erie Railroad Co. v. Tompkins, ${ }^{54}$ both parties to the case sought to preserve Swift v. Tyson, ${ }^{55}$ that is, the federal courts' then-existing practice of applying federal common law in diversity cases. Indeed, Erie's counsel, Theodore Kiendel, saw his primary goal as "preserv[ing] Swift," notwithstanding the fact that Erie would have won under state

${ }^{I}$ Kamen v. Kemper Fin. Servs., Inc., 500 U.S. 90, 99 (1991); see also Teague v. Lane, 489 U.S. 288, 300 (1989) (plurality opinion) (acknowledging the Court's willingness to consider an argument raised only in an amicus brief); Mapp v. Ohio, 367 U.S. 643,646 n.3 (1961) (same), overruled in part on other grounds by Stone v. Powell, 428 U.S. 465 (1976); Estate of Stanford v. Comm'r, 308 U.S. 39, 51 (1939) (“We are not bound to accept, as controlling, stipulations as to questions of law."); Swift \& Co. v. Hocking Calley Ry. Co., 243 U.S. 281, 289 (1917) ("The duty of this court, as of every judicial tribunal, is limited to determining rights of persons or of property, which are actually controverted in the particular case before it... No stipulation of parties or counsel ... can enlarge the power, or affect the duty, of the court in this regard." (quotation marks omitted)). In citing these cases, I do not mean to suggest that courts possess a roving commission to decide any and all questions of law that they deem relevant to the underlying dispute. See infra notes 130-33.

Y/2 Young v. United States, 315 U.S. 257, 259 (1942). It is noteworthy that "[b]ecause personal liberty is most at stake, in the criminal law, the normative force of the rule of law is especially strong and undergirds the maxim 'No crime, no punishment without law." Kenneth Henley, Rule of Law, in 2 PHILOSOPHY OF LAw: AN ENCYCLOPEDLA 765, 766 (Christopher B. Gray ed., 1999).

is It also suggests that, when fashioning equitable relief, federal courts may take account of the "public interest." United States Bancorp Mortgage Co. v. Bonner Mall P'ship, 513 U.S. 18, 26 (1994). For example, in the context of deciding a motion to vacate a judgment (after the parties entered into a setlement agreement, mooting the merits of the case), the Supreme Court has ruled that: "Judicial precedents are presumptively correct and valuable to the legal community as a whole. They are not merely the property of private litigants and should stand unless a court concludes that the public interest would be served by a vacatur."' Id. (quoting Izumi Seimitsu Kogyo Kabushiki Kaisha v. United States Philips Corp., 510 U.S. 27, 40 (1993) (Stevens, J., dissenting)).

304 U.S. 64 (1938) (considering which state's law to apply in a federal diversity case).

41 U.S. (16 Pet.) 1, 19 (1842) (holding that the Rules of Decision Act referred to statutes and local usages, not state common law), overruled by Erie R.R, 304 U.S. at 78. 
Iaw. ${ }^{56}$ Arguing that "[t] he persistent criticisms of Swift ... have largely been misdirected," Kiendel sought to use Swift to his advantage." Consequently, with Tompkins' attorneys firmly committed to Swift, the Justices understood that neither party would call for the overruling of Swift-even if the Court specifically requested briefing on the issue. Whether or not Erie's sua sponte overturning of Swift is a byproduct of this litigation strategy, Erie stands for the proposition that the Court will place adherence to the law ahead of the legal arguments made in court.

Erie is important for another reason. In holding that the parties to a controversy do not control "the choice of law," the Court made clear that it-not the parties-would decide whether a legal argument is or is not waivable. In some (even most) instances, the law contemplates that the parties to a dispute can waive pertinent legal claims. ${ }^{58}$ Other times, however, the law does not allow for waiver. On those occasions, it is the court's responsibility to honor the law, not party preferences. ${ }^{59}$

Another example of this phenomenon is the "gatekeeping role" the courts have assumed in administering the Federal Rules of Evidence. ${ }^{60}$ In sorting out whether to admit expert scientific testimony, for example, a judge "should ... be mindful" of all "applicable rules" of evidence. ${ }^{61}$ More to the point, whenever the Federal Rules of Evidence mandate a particular course of action, it is the court's duty to adhere to the law and take that mandate into account. ${ }^{62}$ That is the lesson of Marbury.

What then of Dickerson? On the one hand, where jurisdiction is clear and the legal issue squarely before the court, Marbury is unequivocal in its demand that the court must make its decision under

\footnotetext{
${ }^{56}$ EdWARd A. PURCELl, JR, BRANDEIS AND THE PROGRESSIVE CONSTITUTION 100 $(2000)$.

${ }_{59}^{57}$ Id. at 100 (quotation marks omitted).

${ }^{59}$ Consider, for example, the Religious Freedom Restoration Act. Under the Act, "[a] person" whose statutory rights have been violated "may assert that violation as a claim or defense in a judicial proceeding." 42 U.S.C. $\$ 2000 \mathrm{bb}-1$ (c) (1994) (emphasis supplied). Here, Congress clearly left it to the affected party to claim or waive her statutory rights, a fact that (before the Supreme Court struck the Act down) several lower courts picked up on in refusing to sua sponte raise the statute.

${ }^{59}$ On questions of facts, parties may stipulate to erroneous facts, including the facts of where a transaction took place (something which would affect the choice of law). Parties, however, may not stipulate to the wrong law.

Daubert v, Merrill Dow Pharm., Inc., 509 U.S. 579, 597 (1993).

${ }^{61}$ Id. at 595 .

${ }^{62}$ And if the mandate is unconstitutional, it is the court's responsibility to invalidate the mandate and thereby adhere to the supreme law.
} 
the governing law. ${ }^{63}$ At the same time, the law includes Article III and, as Marbury makes clear, Article III places real limits on the judicial power. For example, questions irrelevant to the parties in a dispute are presumptively outside the scope of judicial authority. Furthermore, matters committed to the discretion of another branch are outside the purview of judicial review. ${ }^{\text {GH }}$ In the end, Marbury calls upon courts to honor the Framers' admonition that the judicial power (which includes the power to "say what the law is") is "limited to cases of a Judiciary nature." ${ }^{65}$

In applying these principles to Dickerson, the language of the 1968 statute is critically important. If the law grants the executive discretion to choose between Miranda and the 1968 standard, the executive is free to waive its rights under the 1968 statute. But if the law mandates that federal courts-in assessing the admissibility of confessions-adhere to the 1968 standard, courts are duty bound to take that statutory standard into account. Otherwise, rather than "say what the law is," the court would effectively leave it to the parties to stipulate the governing legal standard. ${ }^{66}$ Aside from violating their Article III responsibilities, such an approach would undermine Congress's Article I power to respond to Supreme Court decisions through the enactment of positive law. And while prosecutorial discretion is a core component of the executive's Article II powers, this discretion is in no way undermined by an independent judiciary grounding its decisions in the law." The prosecutor remains free to choose whom it will

\footnotetext{
${ }^{13}$ When there are alternative grounds upon which a court can rule, courts should generally avoid ruling on the constitutionality of an act of Congress. See Ashwander v. Tenn. Valley Auth., 297 U.S. 288, 347 (1936) (Brandeis, J., concurring) ("The Court will not pass upon a constitutional question although properly presented by the record, if there is also present some other ground upon which the case may be disposed of."). Ashwander, howerer, does not permit a court to knowingly apply the wrong legal standard in ruling on a case. Ashwander, moreover, does not allow a court to sub silentio assume that an act of Congress is unconstitutional so that it can avoid ruling on the constitutionality of a statute.

in See Marbury v, Madison, 5 U.S. (1 Cranch) 137, 170 (1803) (noting the limits of the Court's jurisdiction).

652 FARRAND, THE RECORDS OF THE FEDERAL CONVENTION OF 1787, at 430 (1911).

tot For further discussion, see infra Part III (noting that under Article II, the separation of powers also protects executive branch prerogative).

67 The judiciary is only supposed to apply the law, not make law in competition with the legislature. Needless to say, Congress could empower prosecutors with the discretion to employ either the statutory standard or Miranda. See infra Part III (discussing Congress's place within the tripartite system). But the decision is Congress's, not the parties. Prosecutorial discretion is about the choice of whom to prosecute and what evidence to introduce, not the legal theories that the courts will employ. Otherwise, the executive would stand above both Congress and the courts. In particular,
} 
prosecute and to choose what evidence it will introduce at trial. ${ }^{68}$

The 1968 statute, 18 U.S.C. $\$ 3501$, is a command to the courts, not to the executive branch. In other words, while the executive retains discretion over the launching of prosecutions and the introduction of evidence at trial, the executive has no control over the administration of $\S 3501$. Furthermore, $\S 3501$ does not grant judges the discretion to heed or disregard Miranda. The statute, instead, specifies that "[i]n any criminal prosecution brought by the United States ... a confession ... shall be admissible in evidence if it is voluntarily given" and "[ $t]$ he trial judge in determining the issue of voluntariness shall take into consideration all the circumstances surrounding the giving of the confession. ${ }^{169}$ By making use of mandatory language, Congress deemed the prosecution's decision to employ or

courts could not demand that the executive adhere to judicial precedent. See infra note 126 (questioning whether courts can ignore executive policies that the parties do not raise). Likewise, Congress could not restrain the executive through the enactment of positive law by, for example, mandating that certain legal arguments not be waived. This strikes me as a profound violation of both Congress's Article I lawmaking power and the court's power to "say what the law is." See infra note 80 (noting the ramifications of allowing the executive to dictate the legal arguments that a court will consider). For this reason, I think that Erwin Chemerinsky has it backwards when he claims that it is for the Justice Department, not the courts, to determine whether or not to employ the 1968 statute. See Chemerinsky, supra note 18, at 297 ("It thus violates separation of powers for a court to invoke $\$ 3501$ and consider a confession in circumstances in which the Justice Department chose not to use it.").

Of course, the President, as I argue in the next section, is free to interpret the Constitution and reach the conclusion that $\$ 3501$ is unconstitutional. See infra Part III (discussing the President's powers under Article II). Accordingly, notwithstanding what either the courts or Congress says, the President is free to treat Miranda as "law" vis-à-vis executive branch decisionmaking. See infra Part III (noting that the Clinton administration's decision to view Miranda as the governing legal standard was constitutionally protected under Article II). What the President cannot do, however, is run roughshod over the constitutional prerogatives of both the Congress and the courts. For this very reason, I reject the claim that, in Dickerson, the courts should not have ruled on $\$ 3501$ but, instead, should have served as advicegivers-telling the political branches what the law is without issuing a binding precedent (so that the question of whether $\$ 3501$ has legal force, ultimately, is a political matter to be worked out between Congress and the President). See generally Katyal, supra note 28, at 1711 (discussing the Court's role as an advicegiver).

${ }_{68}$ Courts, under Marbury, cannot interfere with matters committed to the discretion of another branch. 5 U.S. (1 Granch) at 170. At the same time, by introducing the confession into evidence, the executive empowers the court to apply the law governing the admissibility of confessions. For this reason, arguments made in Dickerson that the executive had waived the 1968 statute are incorrect.

${ }^{69} 18$ U.S.C. $\$ 3501$ (2000) (emphasis added). 
waive the statute legally irrelevant. Consequently, to look to Miranda in assessing the admissibility of a confession, a court would have to ignore a direct command from Congress to make use of the "totality of circumstances" test. In so doing, rather than abide by its Article III duty to "say what the law is," a court (aware of $\S 3501$ ) would have knowingly applied the wrong legal standard. ${ }^{70}$

More is at stake here than the Article III duty to decide cases consistent with the law. Honoring executive branch preferences, by using the Miranda standard, would make the judiciary an adjunct in the performance of a purely executive function: the implementation of the law consistent with executive branch priorities." ${ }^{n}$ Specifically, if $\$ 3501$, not Miranda, is law, the question of whether Miranda is satisfied is only relevant to those prosecutors who see Miranda as the appropriate policy benchmark for the introduction of confessions. Consequently, assuming that $\$ 3501$ was constitutional, a decision on whether Dickerson's confession satisfied Miranda would have been a decision about the implementation of Department of Justice policy preferences, not a decision grounded in the law.

True, were a court to rule on Miranda, not $\$ 3501$, the binding nature of such a decision would ensure that the court is much more than

\footnotetext{
"Contrary to the plain language of the statute, Erwin Chemerinsky argues that "Congress meant to leave the issue of $\$ 3501$ entirely in the hands of the executive branch." Chemerinsky, supra note 18, at 307. Relying on a brief filed by the House Democratic Leadership, Chemerinsky argues that \$350I was "favored by those "much more interested in election year symboli[sm]" than in overruling Miranda. Id. (quoting Brief of Amicus Curiae House Democratic Leadership at 5, Dickerson v. United States, 120 S. Ct. $2326(2000)$ ). Contrary to this view, the Justice Department's examination of both the language and the history of $\$ 3501$ "confirms that Congress intended Section 3501 to overrule...Miranda." Brief for the United States at 18, United States v. Dickerson, 166 F.3d 667 (4th Cir. 1999) (No. 99-5525); see also Brief of Amici Curiae Senators Orrin G, Hatch et al. at 5, United States v, Dickerson, 166 F.3d 667 (4th Cir. 1999) (No. 99-5525) (noting that $\$ 3501$ supercedes Miranda). Furthermore, even if election year politics was the driving force of $\$ 3501$, the fact remains that the statutory text is an unambiguous command to federal court judges. See Brief of Amicus Curiae of the Bipartisan Legal Advisory Group of the United States House of Representatives at 22 n.25, United States v. Dickerson, 166 F.3d 667 (4th Cir. 1999) (No. 99-5525) (noting that the politics involved in the passage of an act are not grounds for its elimination).

"Alternatively, by asking the court to rule on some standard other than the law, the executive branch is seeking to assume a core judicial function ("say[ing] what the law is"). Whatever characterization one likes, troublesome separation of powers issues are raised when one branch performs the functions of another. See Peter L. Strauss, Fornal and Functional Approaches to Separation-of-Powers Questions-A Foolish Inconsistency?, 72 CORNELL L. REV, 488, 492-96 (1987) (suggesting that the separation of powers, more than anything, is a check against one branch aggrandizing power at the expense of another).
} 
an underling of the executive. ${ }^{72}$ In contrast, were the executive able to override the court and introduce (under $\$ 3501$ ) confessions found inadmissible under Miranda, the court would subordinate itself to the executive. In so doing, there would be a clear violation of one of the principal checks protecting judicial independence, namely the prohibition against advisory opinions. ${ }^{73}$ At the same time, judicial resolution of the Miranda issue-notwithstanding its binding charactercomes perilously close to an advisory ruling. By sidestepping the governing law in favor of a ruling on an ancillary policy question, such a decision would speak only of matters unnecessary to the disposition of the case. ${ }^{74}$ And for the Supreme Court, the prohibition against advi-

${ }^{72}$ For identical reasons, a Supreme Court decision upholding $\$ 3501$ would bind the executive. Specifically, when introducing a confession into evidence, the Justice Department could not circumvent "the law" governing the admissibility of confessions, that is, \$3501. For this reason, I think Erwin Chemerinsky is wrong in arguing that, in Dickerson, government attorneys could nullify $\$ 3501$ simply by choosing "to proceed without the confession or... [by] dismiss[ing] the prosecution against Dickerson." Chemerinsky, supra note 18 , at 305 . Imagine, for example, that the government dismissed its prosecution. Rather than vitiate the Court's ruling, such a decision would call attention to the power of Dickerson-a decision so potent that it affects the government's choice about whom it will prosecute. None of this is to say that the President could not direct U.S. Attorneys to look to Miranda, not Dickerson, in sorting out whether a confession should be introduced into evidence. Furthermore, whenever a federal prosecutor introduced a confession into evidence, the prosecutor could call on the courts to apply Miranda. See infra Part III (discussing power of presidential review). Nevertheless, assuming that the Supreme Court had upheld $\$ 3501$, courts would adhere to $\$ 3501$ and, in this way, bind the President.

${ }^{73}$ While there is significant disagreement over what constitutes an advisory opinion, there is no question that a decision subject to review and modification by the political branches is a constitutionally prohibited advisory opinion. See Lee, supra note 27, at 643-51. The classic Supreme Court statement on this issue is Hayburn's Case, 2 U.S. (2 Dall.) 408 (1792), where the Justices declined to issue nonbinding opinions on the amount of benefits owed to veterans of the Revolutionary War.

${ }^{74}$ Furthermore, if Miranda is a rule of constitutional law, then to decide the admissibility question under Miranda (assuming $\$ 3501$ is constitutional) is in essence to render an unnecessary constitutional ruling. In so doing, the court would violate the prudential (but constitutionally informed) rule against rendering a constitutional determination where a nonconstitutional ground for decision is available. See, e.g., Jean v. Nelson, 472 U.S. 846, 854 (1985) ("Prior to reaching any constitutional questions, federal courts must consider nonconstitutional grounds for decision."); Alma Motor Co. v. Timken-Detroit Axle Co., 329 U.S. 129, 136 (1946) (declaring that courts should not consider the constitutionality of congressional action "unless such adjudication is unavoidable"). And although the Fourth Circuit in Dickerson seems to transgress the related prudential rule against premature adjudication of constitutional questions by not only raising $\$ 3501$ but determining its constitutionality-thus introducing, rather than avoiding, a constitutional question-this move was consistent with the also-related prudential rule favoring a disposition on the narrowest constitutional ground when a constitutional ground cannot be avoided. See Plaut v. Spendthrift Farm, Inc., 514 U.S. 211,217 (1995) (attempting to resolve the case by considering "the narrower ground 
sory opinions (sometimes) stands as a bulwark against rulings on such questions of policy.

One recent example of this phenomenon, United States National Bank of Oregon v. Independent Insurance Agents of America, Inc., ${ }^{75}$ raised an issue quite similar to that presented in Dickerson. Specifically, in a Iawsuit concerning the meaning of a statutory provision, neither party called into question the validity of the underlying statute. Although recognizing that the Court's decision would be binding on the parties, the Justices nonetheless held that a ruling grounded on something other than law would "permit litigants, by agreeing on the legal issue presented, to extract the opinion of a court on hypothetical acts of Congress or dubious constitutional principles, an opinion that would be difficult to characterize as anything but advisory. ${ }^{76}$ For this very reason, the Court suggested that-to avoid rendering an advisory opinion-it must first consider the continuing validity of the underlying statute. ${ }^{77}$ Under this logic, before looking to Miranda to rule on

for adjudication" of two possible constitutional challenges). Specifically, a Mirandabased ruling would apply both to the states and the federal government, whereas a ruling grounded in $\$ 3501$ would apply only to federal prosecutions.

508 U.S. 439 (1993).

"it Id. at 447; see also Steel Co, v. Citizens for a Better Env't, 523 U.S. 83, 101 (1998) (holding that to resolve contested questions of law-even if binding on the partieswhen jurisdiction is in doubt "comes to the same thing as an advisory opinion, disapproved by this Court from the beginning"). On other occasions, however, the Court has signaled that it would not sua sponte consider antecedent legal issues. For example, in validating (under the Federal Arbitration $A c t$ ) a private arbitration agreement the Court refused to consider whether the Act even applied to employment contracts. Gilmer v. Interstate/Johnson Lane Corp., 500 U.S. 20,25 (1991). While acknowledging that several amici discussed the applicability of the Act to employment contracts in their filings, the Court noted that the parties did not "raise the issue in the courts below; it was not addressed there; and it was not among the questions presented in the petition for certiorari." Id. at 25 n.2. What the Court did not mention is that there was a near-unanimous consensus that the Act does apply to employment contracts. In other words, the Justices seem disinclined to sua sponte raise an issue that they do not consider relevant to the case's disposition. For further discussion, see supra note 51 (listing cases where amici, rather than the parties to the case, raised legal issues and theories that proved determinative). See also infra notes 132-33 (suggesting that courts have a duty to raise antecedent legal issues).

${ }^{77}$ At the same time, the Court did not conclusively hold that it had a duty to rule on the ralidity of the underlying statute. In upholding a D.C. Circuit decision (which concluded that there was such a duty), the Supreme Court ruled that the appellate court "had discretion" to consider this issue. Therefore, the Justices saw no reason to decide whether the appellate court was correct in saying that there was a duty to resolve this issue. See Indep. Ins. Agents, 508 U.S. at 447-48 (discussing the appellate court's discretion to consider the issue). The very next year, in Davis v. United States, the Justices refused to sua sponte raise $\$ 3501$ in a ruling on the right to counsel. 512 U.S. 452 (1994). While acknowledging that they have the authority to consider legal arguments that neither party raises, the Justices observed that "we are reluctant to do 
the validity of a confession, a court-to avoid rendering an advisory opinion-would first want to look to $\S 3501$. If it found $\$ 3501$ constitutional, Miranda would be a legal nullity and consequently should not be the basis of decision. Alternatively, if $\$ 3501$ were unconstitutional, Miranda would be the appropriate rule of decision.

Whether or not one accepts Independent Insurance Agents's characterization of what constitutes an advisory opinion, ${ }^{78}$ it is hard to square the grounding of a decision on a legal nullity with the Article III command to "say what the law is." Consider, for example, a ruling on the admissibility of a confession under Miranda, not $\$ 3501$. The precedential effect of such a decision would be quite suspect. After all, the Department of Justice could eschew the Miranda standard in favor of $\S 3501$ or, alternatively, make use of Miranda in some cases and $\S 3501$ in other cases.

To preserve its place in government, the judiciary must respect both the reaches and limits of Article III. Thus, by introducing Dickerson's confession into evidence, the executive opened a Pandora's box that it could not close. Specifically, notwithstanding the parties' failure to raise $\S 3501$, the court had jurisdiction to take into account the law governing the admissibility of confessions. That law (at least until June 26, 2000) included $\$ 3501$. Consequently, whether or not the question of $\S 3501$ 's constitutionality can be cast as a jurisdictional one, a court's Article III responsibility to "say what the law is" strongly supports judicial resolution of the $\$ 3501$ issue. And while inherent limits on a court's ability to discover statutes and regulations (let alone legal arguments) suggest that courts are not under a duty to discover all relevant law, the mandatory nature of $\$ 3501$ suggests that the sua sponte raising of the statute was proper, not simply permissible. ${ }^{79}$

so when the issue is one of first impression involving the interpretation of a federal statute on which the Department of Justice expressly declines to take a position." Id. at 457 n.*. Taken together, these two rulings cast doubt on the Court's suggestion thatto avoid rendering an advisory opinion-it must answer antecedent legal questions by, among other things, determining what legal standard governs the dispute. See also Eric D. Miller, Should Courts Consider 18 U.S.C. \$ 3501 Sua Sponte?, 65 U. CHI. L. REV. 1029, 1039 n.56 (1998) (contending that the Court in Davis may have thought that $\$ 3501$ "should be considered sua sponte at some point in the future").

${ }^{78}$ I do not. Like Evan Lee, I would limit the ban on advisory opinions to judgments subject to review by the political branches and to preenactment review, that is, judgments on laws that have not taken effect See Lee, supra note 27, at 643-44 (describing the various meanings of "advisory opinion"). Moreover, for reasons described above, it is unclear whether the Court really subscribes to this standard. See supra note 77 (discussing the fact that the Court suggests it has authority to render advisory opinons but generally declines not to do so).

${ }^{79}$ See infra notes 132-33 (discussing "rule of law" constraints that limit the court's 
Correspondingly, a Miranda-based ruling would eschew the longstanding presumption that acts of Congress are constitutional and, in so doing, frustrate Congress's Article I prerogative to amend the rules of decision in nonconstitutional cases. ${ }^{80}$ Consequently, until the question of $\S 3501$ 's constitutionality was settled, the courts should have looked for ways not to ground their rulings on Miranda-even if that would have meant the dismissal of the lawsuit.

The Fourth Circuit was correct in sua sponte raising the $\S 3501$ issue in Dickerson. Otherwise (since it thought $\$ 3501$ constitutional), it would have confronted a true no-win situation. Specifically, since the district court suppressed the confession on the basis that it violated Miranda, ${ }^{81}$ the Fourth Circuit thought it had a choice between (a) applying the correct legal standard and allowing the admission of a valid confession or (b) applying the wrong legal standard and keeping the confession out of evidence. In other words, aside from honoring its Article III responsibility to rule on the law, there were strong pragmatic reasons supporting the decision. ${ }^{82}$

power to sua sponte raise legal issues and explaining why those constraints do not apply to Dickerson). Furthermore, to honor both Article III and the rule of law, courts should decide cases according to (their understanding of) the relevant law, including statutes and theories of interpretations uncovered by law clerks, amici, etc. See sufra notes $35-57$ an accompanying text (discussing the analysis courts should make in determining "what the law is"); infra notes 121-33 and accompanying text (describing the need for courts to inform themselves using outside sources in order to determine the "law").

Congress, as the Supreme Court recognized in Dickerson, "retains the ultimate authority to modify or set aside any judicially created rules of evidence and procedure that are not required by the Constitution." $120 \mathrm{~S}$. Ct. at 2332. Title Eighteen of the United States Code $\$ 3501$ was premised on the belief that the Constitution did not mandate the so-called Miranda warnings. See Paul G. Cassell, The Statute that Time Forgot: 18 U.S.C. $\$ 3501$ and the Overhauling of Miranda, 85 IOWA L. REV. 175, 227-31 (1999) (arguing that "the Constitution simply does not require the Miranda rules," which are merely "recommended procedural safeguards"). Consequently, by allowing the executive to dictate the legal arguments that a court will consider, Congress's Article I lawmaking powers would also be subordinated to executive branch desires. While Congress would remain free to use its other powers (appropriations, for example) to pressure the executive into defending the constitutionality of the 1968 statute, Congress could not-consistent with the executive's Article II powers-mandate that the Justice Department defend the statute. See infra notes 89,9496 and accompanying text (describing how the President does not have to concede to all congressional demands). For this very reason, Congress must also look to the courts to protect its lawmaking prerogatives by saying "what the law is."

"See supra note 22.

"12 In contrast, a court that thought $\$ 3501$ unconstitutional, rather than strike the statute down and declare Miranda the governing legal standard, might well prefer ruling on Miranda. Likewise, a court that thought the confession admissible under Miranda might prefer to rule on Miranda and thereby avoid ruling on the constitutionality of $\$ 3501$. By calling attention to circumstances where a court might prefer to 


\section{ARTICLE II AND THE PRESIDENT'S POWER NOT TO EXECUTE UNCONSTITUTIONAL LAWS}

What then of the Article II prerogatives of the executive branch? Just as Article III protects the courts from grounding their decisions on the legal theories subscribed to by the parties to a case, the separation of powers also protects executive branch prerogatives. In particular, by independently interpreting the Constitution, presidents need not adhere to "unconstitutional" acts of Congress or to Supreme Court decisions. While there are some limits to the exercise of this power of presidential review, there is no question about President Clinton's authority to conclude both that $\$ 3501$ was unconstitutional and that the Dickerson confession was admissible under Miranda.

Before turning to the ramifications of presidential review on the Dickerson litigation, a few words on why Article II empowers a President to disavow judicial and legislative interpretations of the Constitution. ${ }^{83}$ First and foremost, by presupposing that a President will check judicial and legislative excess, our tripartite system assumes that the executive is independent from, not subordinate to, Congress and the courts. To maintain that independence, a President must be able to decide for herself what the Constitution means. ${ }^{\text {s4 }}$ The constitutional

sidestep a ruling on $\S 3501$ 's constitutionality, I do not mean to suggest that it is ever appropriate for a federal court to knowingly apply the wrong legal standard. For a general treatment of the circumstances under which courts should avoid ruling on the constitutionality of federal legislation, see Lisa A. Kloppenberg, Avoiding Constitutional Questions, 35 B.C. L. REV. 1003 (1994).

${ }^{83}$ The best known treatments of this subject are Presidential Authority to Decline to Execute Unconstitutional Statutes, 18 Op. Off. Legal Counsel 199 (1994); Frank H. Easterbrook, Presidential Review, 40 CASE W. RES. L. REV. 905 (1990); Michael Stokes Paulsen, The Most Dangerous Branch: Executive Power to Say What the Law Is, 83 GEO. L.J. 217 (1994). While the scholarly literature overwhelmingly supports the power of presidential review, there are some important critics of this position. See, e.g., RAOUL BERger, EXECUTTVE PRIVILEgE: A CONSTTTUTIONAL MYTH 306 (1974) (indicating that presidents are bound to "faithfully execute" all laws, even laws they think unconstitutional); EDWARD S. CORWIN, THE PRESIDENT: OFFICE AND POWERS 1787-1948, at 79 (3d ed. 1948) (same); Arthur S. Miller, The President and the Faithful Execution of the Laws, 40 VAND. L. REV. 389, 396 (1987) (same).

${ }^{84}$ This is true even if the current or prior administration had earlier decided to abide by a judicial ruling or legislative finding. See Jeremy A. Rabkin \& Neal E. Devins, Averting Government by Consent Decree: Constitutional Limits on the Enforcement of Setllements with the Federal Government, 40 STAN. L. REv. 203, 219-26 (1987) (defending the power of one administration not to be bound by the policy preferences of another administration-even if those preferences are grounded in an understanding of the Constitution). For this reason, it is irrelevant whether past administrations (or even the Clinton administration) signaled their belief that 18 U.S.C. \$ 3501 was constitutional. See Cassell, supra note 80 , at 197-225 (highlighting the fact that, prior to arguing in Dickerson that $\$ 3501$ is unconstitutional, every administration, including the Clinton 
text, in significant respects, supports this understanding. By taking an oath to "faithfully execute the Office of the President... [and to] preserve, protect, and defend the Constitution, ${ }^{85}$ a President cannot knowingly act in violation of the Constitution as supreme law, ${ }^{86}$ For this reason, as recognized both in the Federalist Papers and in the debates over the Constitution's ratification, presidential review extends beyond the power to veto legislation on constitutional grounds and to a President's "refus[al] to carry into effect an act that, [in his opinion,] violates the Constitution."

The power of presidential review, moreover, is amply supported by historical practice. Starting with Thomas Jefferson's decision to pardon "every person under punishment or prosecution under" the Alien and Sedition Acts (which criminalized speech critical of the government), presidents-by independently interpreting the Constitution-have departed from the constitutional judgments of Congress and the courts. s. $^{\text {s }}$ The courts also acknowledge presidential review. By appointing counsel to defend legislation that a President is unvilling to defend (rather than hold the President in contempt for failing to defend the constitutionality of Congress's handiwork), the Supreme Court recognizes that "the means [available to a President] to resist

administration, had spoken of its willingness to defend $\$ 3501$ "in an appropriate case"); see also infra note 97 (noting the critiques by the Bipartisan Legal Advisory Group of the United States House of Representatives and Cassell regarding the Department of Justice's chosen legal position). Indeed, "[t]o argue otherwise is ultimately to adopt a theory that says that the basis of law-including a declaration of unconstitutionality-is the court's decision itself." Issues Raised by Foreign Relations Authorization Bill, 14 Op. Off. Legal Counsel 37, 51 (1990) (quoting Professor Sanford Levinson).

U.S. CONST. art. II, $\$ 1$, cl. 8.

Writing in THE FEDERALIST NO, 78, at 524 (Alexander Hamilton) Jacob E. Cooke ed, 1961), Alexander Hamilton observed that " $[n]$ o legislative act ... contrary to the Constitution, can be valid. To deny this would be to affirm that the deputy is greater than his principal; that the servant is above the master; [and] that the representatives of the people are superior to the people themselves." Likewise, in an 1868 letter to Gerrit Smith, Chief Justice Salmon Chase asked rhetorically: "How can the President fulfill his oath to preserve, protect, and defend the Constitution, if he has no right to defend it against an act of Congress sincerely believed by him to have been passed in violation of it?" Issues Raised by Provisions Directing Issuance of Official or Diplomatic Passports, 16 Op. Off. Legal Counsel. 18, 33 (1992) (quoting Chief Justice Chase's letter).

${ }^{37}$ James Wilson, Statement at the Pennsylvania Convention, 1787, in 2 THE DOCUMENTARY HISTORY OF THE RATIFICATION OF THE CONSTITUTION 450 (Merrill Jensen ed, 1976). For a detailed analysis of the Framers' intent, see Paulsen, supra note 83 , at 228-62.

See Neal Devins \& Louis Fisher, Judicial Exclusivity and Political Instability; 84 VA. L. REV. 83, 88-89 (1998) (recounting some notable examples of presidential review). 
legislative encroachment[s]" includes the power "even to disregard [laws]" that a President deems "unconstitutional." ${ }^{\text {"89 }}$ Presidential review, finally, is conceded by Congress. Recognizing that it cannot "entrust the defense of its vital constitutional powers to the advocate[s] for the executive branch, ${ }^{90}$ Congress has enacted legislation requiring the Attorney General to inform it of cases in which the Justice Department will not defend the constitutionality of a federal statute. ${ }^{91}$

In saying that a President need not execute laws that he deems unconstitutional, I do not mean to suggest that there are no constitutional or prudential limits to the exercise of this power. A president, for example, cannot refuse to carry out a judicial order, even if he thinks the order is premised on an incorrect interpretation of the Constitution. That type of nonacquiescence would place a President above the Court, render the judicial power a nullity, and ultimately, cast doubt upon the very foundation of democratic government, namely: the rule of law. ${ }^{92}$ Out of respect for both Congress's lawmak-

${ }^{89}$ Freytag v. Comm'r, 501 U.S. 868, 906 (1991) (Scalia, J. concurring). In addition to Dickerson, the executive has challenged the constitutionality of, among other things, the Federal Election Campaign Act, Buckley v. Valeo, 424 U.S. 1, 6-7 (1976), the legislative veto, INS. v. Chadha, 462 U.S. 919, 925 (1983), the Gramm-Rudman-Hollings Act, Bowsher v. Synar, 478 U.S. 714, 719 n.1 (1986), the Ethics in Govermment Act, Morrison v. Olson, 487 U.S. 654,668 (1988), the Sentencing Reform Act, Mistretta v. United States, 488 U.S. 361 (1989), and diversity preferences in broadcasting, Metro Broadcasting v. FCC, 497 U.S. 547, 551 (1990), overruled by Adarand Constructors, Inc. v. Pena, 515 U.S. 200 (1995). In none of the cases did any member of the Court question the President's power to challenge the constitutionality of an act of Congress.

S. REP. No. 95-170, at 11 (1977).

${ }^{91}$ Department of Justice Appropriation Authorization Act of 1980, Pub. L. No. 96$132, \S 21$ (a) (2), 93 Stat. 1049-50 (1979). Pursuant to this provision, Attorney General Janet Reno, on November 1, 1999, notified the speaker of the House that § 3501 "cannot constitutionally authorize the admission of statements that would be excluded under the Supreme Court's holding in Miranda v. Arizona." Brief of Amicus Curiae of the Bipartisan Legal Advisory Group of the United States House of Representatives at 1, Dickerson v. United States, 120 S. Ct. 2326 (2000) (No. 99-5525).

${ }^{92}$ In subsequent cases, however, the executive branch "may stick to its (legal) guns, asserting in tomorrow's case theories that were rejected in yesterday's." Easterbrook, supra note 83 , at 926 . This is the view expressed by Abraham Lincoln in the matter of Dred Scott, that is, that the Supreme Court's decision was binding on the parties to the case but on no one else. Abraham Lincoln, First Inaugural Address-Final Text (Mar. 4, 1861), in THE COLLECTED WORKS OF ABRAHAM LINCOLN 262, 268 (Roy P. Basler ed., 1953); see also John O. McGinnis, Models of the Opinion Function of the Attomey General: A Normative, Descriplive, and Historical Prolegomenon, 15 CARDOZO L. REV. 375, 389-94 (1993) (describing the "Independent Authority Model" in which the executive branch bears the burden of interpreting the Constitution "independently in carrying out its responsibilities"). As applied to Dickerson, a decision upholding $\$ 3501$ would not bind the executive to apply $\$ 3501$ in future cases. Rather, the executive could continue to use Miranda in sorting out whether to introduce a confession into evidence. And even 
ing prerogatives and the judicial power to interpret the Constitution, moreover, the executive may defend a statute that it thinks unconstitutional. ${ }^{93}$ Office of Legal Counsel opinions allow for a President, as a matter of prudence, to defend constitutionally suspect legislation. According to these opinions: "The President should presume that enactments are constitutional" and should "execute the statute, notwithstanding his own beliefs about the constitutional issue" if he thinks the Supreme Court would sustain the statute. ${ }^{9 / 4}$ Indeed, even "[w]here the President's independent constitutional judgment and his determination of the Court's probable decision converge on a conclusion of unconstitutionality," the President may nonetheless defend the statute in order "to afford the Supreme Court an opportunity to review the constitutional judgment of the legislative branch." ${ }^{95}$ Finally, as a matter of pure politics, the President may cast aside his constitutional objections and enforce a statute rather than risk funding cuts, endless oversight hearings, and other forms of congressional opprobrium.

In the Dickerson case, these principles support the Clinton administration's decision to view Miranda, not $\$ 3501$, as the governing legal standard. By independently interpreting the Constitution, the administration concluded that $\$ 3501$ was unconstitutional and, consequently, should be treated as a legal nullity. While the courts or Congress might disagree with this assessment, the President's decision was

if the courts were to apply $\S 3501$, not Miranda, the executive would not have to speak of $\$ 3501$ in court.

"I I disapprove of this practice. For me, the President's duty to "faithfully execute" the law should stand as a roadblock to the defense of a statute that the President deems unconstitutional.

${ }^{41}$ Presidential Authority to Decline to Execute Unconstitutional Statutes, $18 \mathrm{Op}$. Off. Legal Counsel 199, 200 (1994).

18 Op, Off. Legal Counsel, at 200-01. Along the same lines, Attorney General Benjamin Civiletti wrote in 1980 that "I do not believe that the prerogative of the Executive is to exercise free and independent judgment on constitutional questions presented by Acts of Congress. At the same time, I think that in rare cases the Executive's duty to the constitutional system may require that a statute be challenged ...." The Attorney General's Duty to Defend and Enforce Constitutionally Objectionable Legislation, 4A Op. Off. Legal Counsel 55, 59 (1980).

".6 Mike Paulsen puts it this way: "In a bare-knuckled brawl, Congress can reduce the President to little more than a bureaucrat drawing a fixed salary, vetoing bills, granting pardons, and receiving foreign ambassadors-but without funds for hosting a state dinner (or even taking the ambassador to McDonald's)." Paulsen, supra note 83, at 322 . Furthermore, as a condition of broad delegations of lawmaking power, presidents may agree to arguably unconstitutional limitations on their Article II prerogatives. See Louis Fisher, The Legislative Veto: Invalidated, It Survives, 56 LAw \& CONTEMP. PROBS. 273 (Autumn 1993) (citing numerous examples of presidents agreeing to legislative vetoes as a condition on delegated authority). 
a constitutionally protected exercise of his Article II powers. Correspondingly, it is simply beside the point that the President's decision might run contrary to language in opinions from the Office of Legal Counsel, calling attention to reasons why a President may want to defend a law that he thinks is unconstitutional. ${ }^{97}$ That policy is simply a prudential guideline; it cannot constrain the President's exercise of core Article II powers. ${ }^{98}$

To say that the Justice Department was under no obligation to raise $\$ 3501$, however, does not tell us how a court should respond to that decision. As an Article III matter, courts were under a duty to take $\S 3501$, "the statute governing the admissibility of confessions in federal prosecutions," into account. ${ }^{99}$ What, then, is a court to do? On the one hand, it should have heard arguments both supporting and opposing the constitutionality of $\S 3501$. By "sharpen[ing] the presentation of issues," concrete adversariness improves judicial decision-making by helping to ensure the presentation of a full spectrum of theories, both factual and legal. ${ }^{100}$ On the other hand, a court could not compel the President to defend the statute. Nor could it dismiss the case for want of adversariness. The executive and the criminal defendant were true adversaries; one side claimed the confession admissible, the other disagreed. Consequently, not only would dismissing the lawsuit due to lack of adversariness have been wrong for Article III reasons, it would have undermined the President's Arti-

\footnotetext{
${ }^{97}$ In an amicus brief filed by the Bipartisan Legal Advisory Group of the United States House of Representatives, the Department of Justice was taken to task for deviating from Office of Legal Counsel policy. Noting that the appellate court upheld the statute's constitutionality, the brief argued that there was ample reason to think § 3501 constitutional and, consequently, the Department's refusal to defend was "extraordinary." Brief of Amicus Curiae of the Bipartisan Legal Advisory Group of the United States House of Representatives at 3, Dickerson v. United States, 120 S. Ct. 2326 (2000) (No. 99-5525). Likewise, Court-appointed amicus Paul Cassell criticized the Department for failing to defend $\$ 3501$. Cassell, supra note 80, at 223-25.

${ }^{98}$ Even if the policy were grounded in the President's understanding of the separation of powers, Article II protects the President's power to rethink his views on constitutional questions. See generally Rabkin \& Devins, supra note 84 (discussing constitutional limits on the Court's ability to interfere with or control executive action).

${ }^{99}$ United States v. Alvarez-Sanchez, 511 U.S. 350, 351 (1994); see also supra notes 51-53 and accompanying text (arguing that courts have a duty to look to the law, not solely the arguments advanced by the parties in a controversy).

${ }^{160}$ O'Shea v. Littleton, 414 U.S. 488, 494 (1974) (citation omitted); see also ERWTN CHEMERINSKY, FEDERAL JURISDICTION 40 (1st ed. 1989) ("Because federal courts have limited ability to conduct independent investigations, they must depend on the parties to fully present all relevant information to them. It is thought that adverse parties, with a stake in the outcome of the litigation, will perform this task best.").
} 
cle II power to independently interpret the Constitution. ${ }^{101}$ Specifically, by dismissing the lawsuit, a court would effectively tell the President that all confessions would be kept out of evidence unless and until the President stood ready to defend the applicability of $\S 3501$.

What then is a court to do? It must allow the case to go forward but it cannot compel either party to defend the statute's constitutionality. In the case of the Fourth Circuit (which had no choice but to resolve the dispute over the confession's admissibility), the options, ultimately, were either to determine $\$ 3501$ 's constitutionality without the benefit of arguments defending the statute or, alternatively, to appoint counsel to defend the statute. It chose to appoint counsel and that choice seems reasonable. ${ }^{102}$

${ }^{\text {InI }}$ It is wrong, therefore, to analogize Dickerson to lawmaker challenges to either presidential claims of executive privilege or to a president's war-making and foreign policy powers. In most of those cases, the federal courts have made use of any of a number of the "passive virtues" to avoid rendering a decision on the merits. For example, in tossing out Senator Barry Goldwater's claim that President Jimmy Carter could not unilaterally rescind a treaty with Taiwan, a plurality of the Court concluded that the matter was a "dispute between two coequal branches of our Government, each of which has resources available to protect and assert its interests." Goldwater v. Carter, 444 U.S. 996, 1004 (1979) (Rehnquist, J., concurring). Goldwater suggests that the Court will steer clear of Congress-White House disputes unless and until it has to, that is, unless and until the lawsuit becomes Congress's beef, not the beef of a handful of Congressmen. But unlike Goldwater (where it could leave the matter in the hands of the political branches), the Court could not steer clear of Dickerson. The President, after all, was entitled to argue that the confession should be introduced into evidence. And once the issue of the confession's admissibility was before it, Article III demands that the Court decide the case according to the law.

${ }^{1 / 2}$ What is unreasonable, however, is the Fourth Circuit's apparent lack of interest in hearing arguments challenging the constitutionality of $\S 3501$. True, as the Dickerson majority points out, the Clinton Justice Department was unwilling to reveal its views on this question. At oral argument, counsel for the Justice Department refused to answer questions about $\$ 3501$, explaining that "he had been prohibited by his superiors at the Department of Justice from discussing $\$ 3501$." United States v. Dickerson, 166 F.3d 667, 681 n.14 (4th Cir. 1999); see also Cassell, supra note 80, at 203-23 (highlighting efforts of the Clinton Justice Department to prevent judicial consideration of $\$ 3501)$. At the same time, the appellate court never asked the parties to brief the $\$ 3501$ issue. According to Dickerson's counsel, James Hundley: "The basis for their decision was never identified as an issue on appeal. We didn't brief this issue at all." Carrie Johnson, A Lonely Crusade: Long Running Assault on Miranda Pays Off, LEGAL TIMES, Feb. 15, 1999, at 8. In particular, the order granting the Washington Legal Foundation time to participate in oral arguments came after briefs had been filed in the case. Moreover, although the parties knew full well that the Washington Legal Foundation would raise the $\S 350 \mathrm{I}$ issue, the appellate court's order made no mention of $\$ 3501$.

Unlike the Fourth Circuit, the D.C. Circuit, in Independent Insurance Agents, specifically requested the parties address-both in oral arguments and supplement briefsthe continuing validity of the underlying statute. Petition for a Writ of Certiorari at 6 
The Supreme Court had a somewhat different choice. After all, by denying certiorari, it could have simply sidestepped Dickerson. However, the Justices had good reason to hear the case. ${ }^{103}$ The issue was important and squarely presented. The Justices, moreover, thought the Fourth Circuit was wrong in upholding the statute. ${ }^{104}$ Consequently, a decision denying certiorari would (at least in the Fourth Gircuit) allow into evidence confessions that ought to have been suppressed. By hearing the case, moreover, the Justices could accomplish important institutional objectives. Specifically, by concluding that Congress could not overturn Miranda, the Court could speak of the binding nature of their constitutional decisions on other parts of the government. ${ }^{105}$ In this way, Dickerson allowed the Justices to protect their turf and, in so doing, facilitate the Rehnquist Court's efforts to expand the authority of the Court vis-à-vis Congress. ${ }^{106}$ While the Justices may have preferred a truly adversarial controversy over the constitutionality of $\S 3501,{ }^{107}$ the very real adversariness be-

n.7, United States Nat'1 Bank of Or. v. Indep. Ins. Agents of America, Inc., 508 U.S. 439 (1993) (No. 92-484). In other words, the D.C. Circuit thought it important to ask for briefing and oral arguments on the question that it raised sua sponte. For this reason, there is force to the complaint that the Fourth Circuit was one-sided in its consideration of $\$ 3501$ - upholding the statute "without the benefit of briefing in opposition." Dickerson, 166 F.3d at 695 (Michael, J., dissenting in part and concurring in part). In light of other cases where the Fourth Circuit signaled its interest in resolving the $\S 3501$ issue, there is ample reason to believe that a desire to undo Miranda explains the appellate court's sua sponte raising of $\$ 3501$. See Cassell, supra note 80, at 209-16 (describing Fourth Circuit campaign to consider \$3501); see also supra text accompanying notes 3-9 (identifying criticisms of the Fourth Circuit).

${ }^{103}$ For a valuable treatment on the steps the Supreme Court takes in deciding whether to grant certiorari, see H.W. PERRY, JR., DECIDING TO DECIDE $216-70$ (1991).

${ }^{104}$ Even if the Justices did not think about the merits of Dickerson, there were several other reasons supporting a grant of certiorari. First, the Justice Department supported the petition. Second, because the President claimed that the statute was unconstitutional, there was an apparent conflict between the political branches. Third, because other circuits did not sua sponte raise $\$ 3501$, there was a conflict of sorts between the Fourth Gircuit and other appellate courts.

${ }^{105}$ Dickerson, 120 S. Ct. at 2328 ("While Congress has ultimate authority to modify or set aside any such rules that are not constitutionally required, it may not supersede this Court's decisions interpreting and applying the Constitution." (citations omitted)).

${ }^{106}$ See Greenhouse, supra note 16 (stating that the Court might have overturned the bitterly fought five to four Miranda decision had it not been for its recent, notably strong, desire to protect its constitutional turf against incursions by Congress).

${ }^{107}$ At the same time, there was real advantage in deciding the constitutionality of $\$ 3501$ in a nonadversarial setting. With the Justice Department, as well as the Democratic leadership of the House, arguing that the statute was unconstitutional, the Court's decision does not appear especially countermajoritarian. See Mark A. Graber, The Nonmajoritarian Difficulty: Legislative Deference to the Judiciary, 7 STUD. AM. POL. DEV. 35 (1993) (calling attention to ways in which the political branches encourage the 
tween the Clinton Justice Department and the criminal defendant over the admissibility of the confession was more than enough to support a grant of certiorari in Dickerson. ${ }^{108}$

In saying that the Court did the right thing in Dickerson, I do not mean to suggest that courts ought to search out ways to decide cases in which the executive is unwilling to defend the constitutionality of an act of Congress. ${ }^{169}$ Dickersom is a truly unusual case, involving the confluence of Congress's Article I power to enact rules of procedure in criminal cases, the courts' Article III duty to take those rules into account, a President's Article II power to repudiate those rules, and the presence of a truly adversarial dispute. In other words, the appointment of an amicus in Dickerson is totally consistent with-even mandated by - the "dispute resolution" model of litigation.

Contrast these facts to INS v. Chadha. ${ }^{110}$ In Chadha, the Department of Justice refused to defend the constitutionality of the legislative veto, preferring, instead, to argue that the veto undermined the President's power to execute the law. ${ }^{\text {III }}$ Specifically, the Department thought that a decision by the Attorney General to suspend a deportation was unreviewable by Congress (absent the enactment of legislation which satisfied the Constitution's demands of bicameralism and presentment). Rather than treat the legislative veto as a nullity (by refusing to deport Chadha), however, the Department argued that it was willing to enforce a court ruling upholding the veto. For this reason, the Department argued that the court should settle this "dispute" notwithstanding the case's apparent lack of adversariness. Agreeing with this rationale, the Ninth Circuit Court of Appeals assured an "adversary presentation of the issues" by allowing the House of Representatives and Senate to intervene in Chadha (but only after hearing oral

Court to strike laws down).

${ }^{10 m}$ Furthermore, considering the number of years it took for a lower court to sua sponte raise $\$ 3501$ (and with little reason to think-after thirty years of not invoking $\$ 3501$ - that the Justice Department would make use of the statute), there was reason to doubt the prospect of a truly adversarial controversy over the applicability of $\S 3501$.

${ }^{1 i r}$ Courts can accomplish this feat either by appointing amici to defend the statute (as they did in Dickerson) or by broadening the rules of intervention to parties who otherwise do not have standing.

11v 462 U.S. 919 (1983).

111 See Brief for the Immigration and Naturalization Service at 15-64, INS v. Chadha, 462 U.S. 919 (1983) (Nos. 80-1832, 80-2170, \& 80-2171) (arguing that a legislative veto would allow Congress to pass general legislation authorizing one or both of its houses to veto any decision or order of the President or other officer of the United States); see also BARBARA HINKSON CRAIG, CHADHA: THE STORY OF AN EPIC CONSTITUTIONAL STRUGGLE 148-87 (1990 ed.) (discussing Department of Justice decisionmaking in Chadha litigation). 
arguments in the case!). ${ }^{112}$ The Supreme Court went along with the Justice Department's campaign for a definitive judicial resolution of the legislative veto's constitutionality. ${ }^{113}$ But, it should not have. Unlike Dickerson, a decision dismissing the case would not have interfered with the President's Article II powers to both interpret the Constitution and "faithfully execute the laws." The only thing preventing the Attorney General from suspending Chadha's deportation was his hope that the Supreme Court would rule on the constitutionality of the legislative veto. Correspondingly, as an Article III matter, the Chadha litigation was an abomination. ${ }^{114}$ The desire for a court decision, in and of itself, does not support judicial resolution of a case in which there is no disagreement.

The lesson here is simple. A President's power to interpret the Constitution is not the power to demand judicial rulings on these interpretations. ${ }^{115}$ Sometimes a President and Congress need to do bat-

${ }^{112}$ See Jurisdictional Statement at 13 n.9, INS v. Chadha, 462 U.S. 919 (1983) (No. 80-1832) (explaining why Chadha satisfies the case or controversy requirement). Ironically, in filing a motion to intervene in Chadha, the House and Senate sought a rehearing en banc with the express purpose of "argu[ing] that the Ninth Panel that had heard the case had erred in granting jurisdiction because there had been no adverseness." CRAIG, supra note 111, at 166; see Brief of the United States House of Representatives at 41-50, INS v. Chadha, 462 U.S. 919 (1983) (Nos. 80-1832, 80-2170, \& 80-2171) (arguing that the Court was without jurisdiction to decide Chadha).

${ }^{113}$ The Justice Department saw Chadha as the perfect vehicle to challenge the legislative veto. By finding that Chadha did not meet the statutory requirements of "hardship," the legislative veto became a clear intrusion into the executive's power to implement the law. See CRAIG, supra note 1I1, at 167 (proposing that in Chadha the Justice Department was seeking the Court's "stamp of approval"). For this reason, Chadha, not Dickerson, may be the emblematic case of conservatives willing to suspend their campaign against judicial activism in order to advance their ideological agenda in court.

${ }^{114}$ My complaint here is that the courts created a case or controversy by allowing de facto legislative standing without the usual requisites. Indeed, there was good reason to think that Chadha was moot. By marrying an American citizen, Chadha was entitled to stay in the United States. See 8 U.S.C. \$1430(b) (1994) ("Any person ... whose spouse is ... a citizen of the United States .... may be naturalized upon compliance with all the requirements of the naturalization laws. ..."). Of course, it may be that the Justices reached out to decide Chadha because they were eager to strike down the legislative veto. But this desire to expound on the Constitution's meaning should give way to the jurisdictional demands of Article III. See Vt. Agency of Natural Res. v. United States ex rel. Stevens, 120 S. Ct. 1858, 1862 (2000); see also infra note 116 (arguing that the Court wrongfully appointed amicus in the Bob Jones case in order to further certain political goals).

${ }^{115}$ See Michael Stokes Paulson, Nixon Now: The Courts and the Presidency After Twenty-Five Years, 83 MINN. L. REv. 1337, 1363-66 (1999) (highlighting the absurdity of Nixon, who on the one hand claimed absolute immunity from compulsory judicial process, while on the other hand came to the courts, hat in hand, asking for the courts 
tle with each other over the Constitution's meaning. ${ }^{116}$ In Chadha, the President's squabble was with Congress. While seeking cover behind a court ruling may have made political sense to the President, ${ }^{117}$ he should have taken his complaint to the Congress. ${ }^{118}$ Sometimes, however, courts should intercede in what appears to be a dispute between the political branches. In Dickerson, the presence of a clearly adversarial dispute necessitated the appointment of an amicus to defend $\$ 3501$. Otherwise, the President's Article II power to independently interpret the Constitution would have been jeopardized. In the end, fidelity to the separation of powers-not a desire to enhance the judiciary's power to expound on public values-may well explain the Court's action in Dickerson. ${ }^{119}$

\section{THE RULE OF LAW AND DICKERSON}

In the preceding pages, I have argued that the judiciary's Article III responsibility to "say what the law is" and the President's Article II

to say that this is so).

11. For this very reason, the Court was wrong to appoint amicus to argue the "gorernment's side ${ }^{\prime}$ in Bob Jones Universily v. United States, 461 U.S. 574, $599 \mathrm{n.24}$ (1983). In $B o b$ Jones, both parties agreed that the University was entitled to tax-exempt status, notwithstanding its religiously based policies against interracial dating and marriage by students. See generally Thomas McCoy \& Neal Devins, Standing and Adverseness in Challenges of Tax Exemptions for Discriminalory Privale Schools, 52 FORDHAM L. REV. 441, 462-64 (1984) (describing the Court's actions in Bob Jomes as an attempt to legislate on a politically controversial issue when there was no longer a need for judicial resolution). Nevertheless, the political cost of granting a tax break to Bob Jones University was too much for the Reagan administration. Consequently, after announcing its plan to restore Bob Jones University's tax-exempt status (and petitioning the Supreme Court to moot the school's challenge to the government's earlier denial of tax-exempt status), the administration once again reversed course-this time asking the Justices to appoint counsel to defend the government's earlier practice of denying tax breaks to racist schools. Id. Rather than grant this request, the Court should have forced the administration to bear the costs of a politically unpopular decision.

${ }^{217}$ As a matter of pure politics, presidents have always found that the benefits of agreeing to the legislative veto-expansive delegations of power-have always outweighed the costs-conditions on the exercise of delegated power. See generally Fisher, supra note 96, at 277-84 (noting several presidents who have agreed to legislative vetoes as a condition on delegated authority). For this reason, the White House had much to gain in seeking the judicial invalidation of the legislative veto.

${ }^{11}$ This, after all, is the logic of Goldwater v. Carter, 444 U.S. 996, 997 (1979) ("The Judicial Branch should not decide issues affecting the allocation of power between the President and Congress until the political branches reach a constitutional impasse."), and other cases denying lawmakers standing to challenge executive branch decisionmaking. With respect to the legislative veto, the President could take his complaint to Congress simply by refusing to enforce or to sign bills with legislative veto provisions.

${ }^{114}$ It is also possible that the Court sought to resolve the dispute and expound on public constitutional values. 
power to independently interpret the Constitution support both the sua sponte raising of the 1968 statute and the appointment of counsel to defend the constitutionality of the statute. ${ }^{120}$ But, much more than the separation of powers is at stake in Dickerson. A decision forbidding the courts' consideration of legal theories not raised by the litigants would cast doubt on the rule of law.

Let me explain. The rule of law is anchored in the belief that law is binding (especially on the sovereign) and, consequently, that the administration of law must conform with the declared rule. ${ }^{121}$ By authoritatively settling what is to be done, the rule of law fosters "the virtues of reliance, predictability, and stability[, and] by reducing variance in individual cases," the rule of law allows both individuals and government officials to plan their lives. ${ }^{122}$ Needless to say, the law is subject to interpretation. Furthermore, executive officials, especially prosecutors, possess significant discretion in administering the law. At the same time, the rule of law presupposes that an independent judiciary will base its decisionmaking on the law, not the policy priorities of the executive branch. ${ }^{123}$

Imagine the alternative, that is, a regime in which the parties to a dispute define the "law." Courts, lacking the power to independently look to the governing law, would rule under the terms and conditions of the parties who pursue litigation. Most of the time, one or the other party will have real incentives to call attention to the governing law. That, of course, is the premise of the adversarial system, namely, that the parties to a dispute will seek to advance their cause by advancing all pertinent legal arguments that support their position. Some of

${ }^{120}$ By taking the 1968 law into account, the courts also gave meaning to Congress's Article I power to legislate rules of evidence. See supra note 67 (contrasting Congress's lawmaking power with the judiciary's power to "say what the law is").

${ }^{121}$ See generally LON L. FULLER, THE MORALITY OF LAW 33-41, $81-91$ (1964) (discussing the importance of congruity between the rules as announced and their actual administration). "Rule must be by law and not discretion" so that "the lawmaker itself must be under the law," Allan C. Hutchinson \& Patrick Monahan, Democracy and the Rule of Law, in THE RULE OF LAW: IDEAL OR IDEOLOGY 97, 101 (Allan C. Hutchinson \& Patrick Monahan eds., 1987); see also Ian Shapiro, Introduction, in THE RULE OF LAW 1, 5,10 n.4 (Ian Shapiro ed., 1994) (discussing how judges decide cases based on black letter law as well as other legal standards).

${ }^{122}$ Macedo, supra note 40, at 154; see also Larry Alexander \& Frederick Schauer, On Extrajudicial Conslitutional Interpretation, 110 HARV. L. REV. 1359, 1371-81 (1997) (discussing the settlement function of law).

${ }^{123}$ See supra note 71 and accompanying text (discussing the influence of the executive branch upon the judiciary in light of the separation of powers doctrine). Of course, to faithfully execute the law, the executive must interpret the law and, in so doing, may look for ways to integrate its policy priorities into the law. 
the time, however, neither party will have incentive to call the governing law to the court's attention. This was true of Dickerson, Erie, and, to a certain extent, Marbury. ${ }^{124}$ On other occasions, moreover, a party quite willing to raise an issue will not. This may be a result of bad lawyering or the simple failure to realize that the court is interested in, say, reconsidering a longstanding interpretation of the Constitution or some federal statute. This was true in Independent Insurance Agents as well as a host of cases where courts have looked to amicus briefs and other sources to glean the appropriate legal standard to apply. ${ }^{125}$

The costs of leaving it to opposing counsel to call the governing law to the court's attention cannot be overestimated. In such a regime, precedent would give way to party arguments-so that the law would no longer act as a stabilizing force. ${ }^{126}$ Furthermore, an independent judiciary would no longer see to it that the sovereign operated within the rule of law; instead, it would be up to opposing counsel to call the governing law to the court's attention. Take the Dickerson case. For more than thirty years, the Justice Department steered clear of the 1968 statute. As such, there was little reason to think that the Department would employ (what all, including the Supreme Court, recognized to be) "the statute governing the admissibility of confessions in federal prosecutions., ${ }^{127}$ Far more significant, had some prosecutor pursued the 1968 statute and prevailed, the Justice

${ }^{124}$ See supra text accompanying notes 24 (discussing instances in Dickerson where both sides ignored the 1968 statute); supra text accompanying notes 5455 (discussing Erie where both sides deliberately neglected ta call for the overruling of Swift). In Marbury, Madison chose to thumb his nose at the Federalist Supreme Court by ignoring the lawsuit. See DONALD DEWEY, MARSHALL v. JEFrersON: THE POLITICAL BACKGROUND OF MARBURY V. MADISON 96-99 (1970). Consequently, the issue of the Court's jurisdiction to issue Marbury a writ of mandamus was not challenged by either party to the litigation. For further discussion, see supra notes $32,49,50$ and accompanying text.

12. Indep. Ins. Agents v. Clarke, 955 F.2d 731 (D.C. Cir. 1992), rev'd on other grounds, 508 U.S. 439 (1993) (listing Teague v. Lane and Mapp v. Ohio, as examples of cases where the Supreme Court looked to amicus briefs); see also supra text accompanying notes 75-78 (listing Independent Insurance Agents and the possible negative effects of making a ruling based on something other than the law).

${ }^{126}$ Imagine the following hypothetical: The Supreme Court overrules Miranda in a 1995 decision. The Clinton Justice Department, however, thinks that decision incorrect and, consequently, continues to utilize Miranda. Should a lower federal court judge (undoubtedly aware of the 1995 decision) pretend the new rule doesn't exist because neither party raises it? If the answer to this question is no-lower court judges must adhere to Supreme Court precedent-is there any principled reason to distinguish the above facts from the situation in Dickerson, namely, the efforts of litigants to treat duly enacted, presumably constitutional, nonwaivable legislation as a nullity?

${ }^{127}$ United States y. Alvarez-Sanchez, 511 U.S. 350, 351 (1994). 
Department would be under no obligation to treat that decision as binding precedent. Rather, assuming that the criminal defendant agreed, the Department (simply by refusing to mention the statute) could demand that the courts adhere to Miranda in subsequent cases. Indeed, the Justice Department and criminal defendants could stipulate that the governing standard is something altogether different than either Miranda or the 1968 statute. In other words, the rule of law would be replaced by the rule of men. ${ }^{128}$

My point here is not that the rule of law presupposes that courts see themselves as an expositor of norms, nor as resolvers of individual disputes. ${ }^{129}$ It is, instead, that courts should not knowingly apply the wrong legal standard. When an issue is squarely before the court (as was the admissibility of Dickerson's confession), courts must look to the law, not just the arguments of the parties before it. ${ }^{130}$ In other words, notwithstanding our commitment to the adversarial system,

there must be enough play in the joints that [a federal court] need not render judgment on the basis of a rule of law whose nonexistence is apparent on the face of things, simply because the parties agree upon it-

${ }^{128}$ In Dickerson, the rule of men (adherence to Miranda irrespective of the constitutionality of the 1968 statute) was more protective of the criminal defendant than the rule of law (adherence to the 1968 statute unless that statute was found unconstitutional). In another case, however, the rule of men might be less rights-protective than the rule of law. For example, proposed legislation would require federal courts to order DNA testing from the crime scene, at government expense if the accused cannot pay for it. James Q. Wilson, What Death-Penalty Errors?, N.Y. TimES, July 10, 2000, at A19. Under the rule of law, a federal court would be obligated to order such testing irrespective of whether counsel for the accused made a request for such testing.

${ }_{129}$ I therefore disagree with scholarly efforts to link the rule of law to the "public values" model of litigation. See, e.g., Matthew Diller \& Nancy Morawetz, Intracircuit Nonacquiescence and the Breakdown of the Rule of Law: A Response to Estreicher and Revesz, 99 YALE L.J. 801, 803-04 (1990) (asserting that the judicial branch's ability to establish a rule of law enables the branch to serve as an expositor of norms). Consider, for example, the rule of law demand that a court must first satisfy itself that it has jurisdiction before it addresses the merits of a dispute. For a proponent of the "dispute resolution" model, the rule of law is honored by treating jurisdiction as a very real constraint on a court's power to "say what the law is." In contrast, proponents of the "public values" model would treat jurisdiction as a de minimis constraint on the judiciary's power to speak to the merits.

${ }^{130}$ This is especially true when Congress has enacted legislation prohibiting parties from waiving a legal theory in support of their claim. By mandating judicial consideration of that legal theory, Congress-consistent with its supervisory powers over the federal courts-has defined which legal issues should be before the court. Of course, as was true in Dickerson, a court can claim that Congress acted unconstitutionally. But it cannot claim that principles of judicial economy prevent it from sua sponte considering matters that neither party raised in their filings. See supra notes $32,51,129$ and accompanying text (arguing that the judiciary's raising of sua sponte issues conforms to the "dispute resolution" model of litigation). 
particularly when the judgment will reinforce error already prevalent in the system. ${ }^{13 t}$

Judges, then, should look to party filings, their own knowledge of the law, the research of their law clerks, amicus filings, and the like, to inform themselves. And when statutory language mandates judicial consideration of an issue $o r$ when the court is convinced that the parties before it are seeking a decision on something other than the law, judges must be willing to frustrate party expectations by grounding their decision in "the law," not in party arguments. ${ }^{132}$ By "saying what the law is," judges will honor both their Article III independence and the rule of law. ${ }^{133}$ In so doing, the courts will be able to perform their most important task-legitimating the actions of elected government.

${ }^{131}$ United States v. Burke, 504 U.S. 229, 246 (1992) (Scalia, J., concurring). For this reason, I think that D.C. Circuit judge Laurence Silberman goes too far in calling for court decisionmaking to (almost always) be limited to party arguments. See Indep. Ins, Agents of America, Inc, v. Clarke, 955 F.2d 731, 741-44 (D.C. Cir. 1992) (Silberman, dissenting) (arguing that courts are not self-directed boards of legal inquiry), rev'd on other grounds, 508 U.S. 439 (1993); United States v. Pryce, 938 F.2d 1343, 1353 (1991) (Silberman, J., dissenting in part) ("We thus ordinarily have no right to consider issues not raised by a party in either briefing or argument, both because our system assumes and depends upon the assistance of counsel, and because of the unfairness of such a practice to the other party. ${ }^{n}$ (citations omitted)).

${ }^{132}$ For this reason, the decision to sua sponte raise $\$ 3501$ in Dickerson was proper, not simply permissible. At the same time, to ensure that judges operate within the rule of law, it is imperative that judges limit those occasions on which they sua sponte raise legal arguments. The types of cases where courts should sua sponte raise arguments not considered by the parties are jurisdictional issues, matters on which Congress has mandated that parties cannot waive a particular legal claim, and issues of statutory construction where there is reason to doubt the continuing validity of the underlying statute. Beyond these categories, courts should only raise a legal theory to prevent themselves from knowingly grounding their decisions in the wrong legal standard.

Even within these categories, judges should exercise some restraint. For example, judges should be especially cautious about sua sponte raising issues that they consider close questions. In part, a truly adversarial presentation will facilitate their resolution of such disputes. Furthermore, the more willing judges are to raise such issues, the greater the risk that judges will see their power to decide cases as part and parcel of an unbounded commission to expound on the meaning of federal law. See Kamen v. Kemper Fin. Servs., Inc. 500 U.S. 90, 97 n.4, 99 (1991) (leaving "for another day" one antecedent legal issue not raised by the parties while resolving another antecedent legal issue as part of its "power to identify and apply the proper construction of governing law"). By limiting themselves this way, judges will be constrained by the rule of law. In contrast, an open-ended rule which allows judges to raise whatever legal arguments they find of interest would risk transforming the rule of law into a judge-dominated rule of man.

${ }^{185}$ I do not mean to suggest here that federal court judges have a duty to search out all relevant law on each and every legal issue that they confront. Limitations in judicial resources would make such an undertaking impossible. But, when confronted with relevant law, judges cannot avert their eyes and look only to party arguments. 
"What a government of limited powers needs, at the beginning and forever, is some means of satisfying the people that it has taken all steps humanly possible to stay within its powers. ${ }^{\text {is: }}$

In Dickerson, the Justice Department claim that Miranda, not the 1968 statute, is the standard governing the admissibility of confessions has now been validated by the Supreme Court. In other words, by sua sponte raising the 1968 statute and by appointing counsel to defend the statute, the judiciary has legitimated this Justice Department position. In contrast, a decision steering clear of the 1968 statute, because neither party invoked it, would have cast doubt on this Justice Department position. More fundamentally, such a decision would suggest that the President-at least sometimes-is not bound by the law.

Of course, the Supreme Court could have upheld the 1968 statute, Had this occurred, the President might well have resisted the Court (and Congress) by continuing to utilize the Miranda standard. Even here, however, the Constitution would be made more vibrant and stable. The logic of our system of checks and balances, as Alexander Bickel wrote, is that "the effectiveness of the whole depends on [each branch's] involvement with one another... even if it often is the sweaty intimacy of creatures locked in combat. ${ }^{\text {"185 }}$ More to the point, by exercising his power of presidential review, the meaning of the Fifth Amendment right against self-incrimination would play out in a dialogue between the branches and the people. For example, by continuing to argue that Miranda is the appropriate benchmark, the executive could press its case to the courts-to reconsider their ruling - to the Congress-to repeal the 1968 statute-and to the people-to use the ballot box and other mechanisms to support Miranda.

\section{CONCLUSION}

The separation of powers and the rule of law both support the sua sponte raising of the 1968 statute and appointment of counsel to defend the statute. While a desire to undo Miranda may have been the motivation for all this, ${ }^{196}$ it is nevertheless true that a court committed to judicial restraint would have followed a similar course. Just as a president must independently interpret the Constitution, courts must

194 Charles L. BLACK, JR., THE People AND the COURT 52 (1960).

135 ALEXANDER M. BICKEL, THE LEAST DANGEROUS BRANCH 261 (1962).

${ }^{156}$ See supra notes 10-16, 102 and accompanying text (discussing the Fourth Circuit's motivation to sua sponte consider the 1968 statute). 
exercise their power to "say what the law is." tite system of government and, with it, our commitment to the rule of law will collapse.

${ }^{137}$ Article I values are also implicated; in particular, Congress's supervisory power over the rules of evidence. See supra note 120 (discussing Congress's lawmaking power). 